Nevşehir Bilim ve Teknoloji Dergisi TARGíD Özel Sayı 214-227 2016

DOI: 10.17100/nevbiltek.211001

URL: http://dx.doi.org/10.17100/nevbiltek.211001

\title{
Sarımsak Yetiştiriciliğinde Farklı Bakteri Biyoformülasyonu Uygulamalarının Bitki Gelişimi Parametreleri, Verim ve Enzim Düzeyleri Üzerine Etkisi
}

\author{
Aslıhan Esringü ${ }^{1 *}$, Recep Kotan², Fatih Bayram², Melek Ekinci ${ }^{3}$, Ertan Yıldırım³, Hayrunnisa Nadaroğlu ${ }^{4}$, \\ Hikmet Katırcıŏlu ${ }^{5}$ \\ ${ }^{1}$ Atatürk Üniversitesi, Narman Meslek Yüksekokulu, Narman-Erzurum \\ ${ }^{2}$ Atatürk Üniversitesi, Ziraat Fakültesi, Bitki Koruma Bölümü, Erzurum \\ ${ }^{3}$ Atatürk Üniversitesi, Ziraat Fakültesi, Bahçe Bitkileri Bölümü, Erzurum \\ ${ }^{4}$ Atatürk Üniversitesi, Erzurum Meslek Yüksekokulu, Erzurum \\ ${ }^{5}$ Gazi Üniversitesi, Eğitim Fakültesi, Biyoloji Bölümü, Ankara \\ Öz \\ Bu çalışmada; yabani ve kültür bitkilerinin toprak altı veya toprak üstü aksamlarından daha önce yürütülen bazı çalışmalarda izole edilerek \\ tanılanan, toplam 1248 bakteri izolatı içerisinden seçilen Agrobacterium sp., Bacillus sp., Pantoea sp. ve Pseudomonas sp.'e ait toplam 19 \\ adet bakteri izolatı kullanılarak 3 farklı bakteri biyoformülasyonu (F1, F2 ve F3) hazırlanmıştır. Bu biyoformülasyonlar içerisine daldırılan \\ sarımsak (Allium sativum L.) dişleri saksılara ekilerek uygulamaların bitki boyu, klorofil düzeyi ve bazı enzim (katalaz, peroksidaz, polifenol \\ oksidaz ve superoksit dismutaz) aktiviteleri üzerine etkileri saptanmıştır. Tüm bakteri formülasyonu uygulamalarının kontrole göre \\ sarımsakta bitki gelişiminde önemli katkılar sağladığı ve bitki enzim düzeylerinde de önemli değişikliklere sebep olduğu görülmüştür. Sonuç \\ olarak; test edilen 3 bakteri biyoformülasyonu içerisinde özellikle B2 formülasyonunun hem bitki gelişim parametreleri hem de bitkideki \\ enzim düzeyleri bakımından yapılan değerlendirmede sarımsak tarımında mikrobiyal gübre olarak kullanılabileceği düşünülmektedir.
}

Anahtar Kelimeler: Antioksidant enzim, Bakteri, Biyogübre, PGPR, Sarımsak

\section{The Effect of Different Bacteria Biofotmulation Applications on Plant Growth, Yield And Enzyme Levels in Garlic Cultivation}

\begin{abstract}
In this study, we have prepared 3 different bacteria bioformulation (F1, F2 and F3) by using a total 19 bacteria isolates belonging to Agrobacterium sp., Bacillus sp., Pantoea sp.and Pseudomonas sp. chosen and identidfied 1248 bacteria isolate from underground or above ground parts of the wild and cultivated plants in several studies conducted previously. Cloves of garlic (Allium sativum L.) that had been submerged into these bioformulations were potted and had been determined their effects on plant height, chlorophyll level and some enzyme (catalase, peroxidase, polyphenol oxidase and superoxide dismutase) activities. It has been found out that all bacteria formulation treatments made important contributions to the plant growth of garlic compared to the control, and caused important changes in the plant enzyme levels. As a result, it is thought that B2 formulation, among the three bacteria bioformulations tested, could be used a microbial fertilizer in garlic agriculture due to its plant growth parameters and enzyme levels in plant.
\end{abstract}

Keywords: Antioxidant enzymes, Bacteria, Bio fertilizer, PGPR, Garlic

*e-mail: esringua@atauni.edu.tr 


\section{Giriş}

Yoğun kimyasal girdi kullanımına bağlı olarak tüm dünyada olduğu gibi ülkemizde de tarım arazilerindeki toprakların fiziksel ve kimyasal özellikleri değişime uğramıştır. Hatta, çok uzun yıllardır ve bilinçsizce kullanılan bu kimyasal bitki besleme ve bitki koruma ürünlerinden dolayı doğal denge bozulmuş, çevre kirliliği ve sağlık açısından ciddi risklerle karşı karşıya kalınmıştır. Toprakta eşsiz bir uyum içerisinde var olan mikroorganizmalar, günümüzde uygulanan yanlış üretim teknikleri yüzünden kayba uğramış ve beraberinde birçok sorunu getirmiştir. Bu yüzden; çalışmalar, tarımda kullanılan kimyasal gübre ve pestisitlere alternatif yöntemler üzerinde yoğunlaşmıştır. Bu nedenle yararlı mikroorganizmaların sürdürülebilir tarım için toprağa dışarıdan takviyesi gerektiği fikri benimsenmiştir. Toprakta yaşayan ve bitki lehine çalışarak bitki büyümesini destekleyen bu faydalı organizmalar günümüzde Bitki Büyümesini Teşvik Eden Rizobakteriler (PGPR) olarak bilinmektedir. PGPR'ların çoğunluğu bitki kök bölgesinde doğal olarak yaşamlarını sürdürürler [1]. PGPR uygulamaları doğrudan ya da dolaylı olarak bitki büyümesini ve gelişimini etkilemektedirler. Bu mikroorganizmalar; gerek antagonistik etkileri gerekse toprakların makro ve mikro besin element miktarlarını, toprak Ph'sı, toprak nem içeriği, toprak havalanma durumu, toprak sıcaklığı gibi çeşitli toprak özellikleri yanısıra tohum çimlenmesi, kök gelişimi, bitkinin sudan yararlanması, büyüme hormonlarının üretilmesi, çeşitli viral hastalıklara karşı koruma sağlaması gibi çok farklı olumlu etkiler göstererek bitkisel üretime katkıda bulunmaktadırlar [2-4]

Büyük miktarlarda ve ekonomik düzeyde sarımsak üretimi deniz ikliminden kara iklimine geçiş bölgelerinde yapılır ve çevre şartlarına iyi adapte olabilen bir sebzedir. Yetiştirme döneminde optimum gelişmeyi $15-20{ }^{\circ} \mathrm{C}$ sıcaklıklarda \%60-80 nemli ortamlarda gösterir. Sarımsak (Allium sativum L.) bitkisi zambakgiller (Liliaceae) familyasından, soğanlı, içi boş, dik saplı ve iki yıllık otsu bitkidir. Üretim şekli ise soğancıkları (diş) ile üretilir. Anavatanı Hindistan olmasına rağmen günümüzde, Batı, Güney ve Orta Asya ile Avrupa, Kuzey Afrika, Çin, Hindistan, Mısır, ABD, Meksika ve Türkiye'de de yetiştirilmektedir. Türkiye, sarımsak üretiminde söz sahibi ülkeler arasında olup; dünya sarımsak üretimi içerisinde yaklaşık \% 4'lük pay ile yedinci sırada yer almaktadır [5-6]. Türkiye'de 2014 y1lı tarım istatistik verilerine göre 91000 ton/y1l sarımsak üretilmektedir. Sarımsak gıda olarak kullanımının yanında tahmini olarak 4000 yıldır kalp kaslarına olan faydaları, sinir sistemi üzerine olumlu etkileri ve tansiyon düzenleyici etkisi ile tıbbi bir bitki olarak kullanılmaktadır [7].

Toprak verimliğini artırmada en önemli faktörlerden biriside bitki besin elementleridir ve bu elementler bitki gelişimine önemli düzeyde katkıda bulunmaktadırlar. Bu elementler bitki tarafından toprak çözeltisinde çözünmüş halde ya da toprağın katı fazında adsorbe edilmiş halde tutulan mineral maddelerden alınır. Toprak çözeltisinde eksilen bu elementler dışardan kimyasal ve organik gübre takviyesi şeklinde veya toprakta mevcutta bulunan toprak organik maddesinin parçalanmasıyla bitkiye sağlanır. Toprak organik maddesinin parçalanmasında toprakta bulunan mikroorganizmalar en etkin rolü oynamaktadır. Sarımsağın gerek iç piyasada gerekse dış piyasada pazar bulabilmesi, yetiştirilen sarımsağın beslenme düzeyine ve kalitesine bağlıdır. Sarımsakta kaliteyi ve dayanıklılığı artırmada önemli rol oynayan potasyuma gereken önemin verilmediği de bilinmektedir. Sarımsakta iyi bir ürün için tınlı kumlu toprağa ihtiyaç duyulduğunu ve $200 \mathrm{~kg} / \mathrm{ha} \mathrm{N}, 250 \mathrm{~kg} / \mathrm{ha}$ $\mathrm{K}_{2} \mathrm{O}$ ve $100 \mathrm{~kg} / \mathrm{ha} \mathrm{P}_{2} \mathrm{O}_{5}$ uygulamasının yararlı olacağı belirtilmiştir [8]. Yani sarımsak yetiştiriciliğin de bitkisel üretimdeki pek çok bitki gibi yine dışardan yoğun bir kimyasal gübre uygulaması gerektirmektedir. 
Sarımsak bitkisinin bitki büyüme parametreleri üzerine Azotobacter+Phosphobacteria biyogübre uygulamasının Azospirillium+phophobacteria uygulamasından daha fazla etkili olduğu yapılan bir çalışmada bildirilmiştir [9]. İki farklı (Balady and Chinese) sarımsak çeşidinin bitki gelişimi, soğan kalitesi, verimi ve depolanabilirlik parametreleri üzerine azot fikse eden bir bakteri olan Halex-2 ve humik asit uygulamasının her iki sarımsak çeşidinde de etkili olduğunu tespit edilmiştir [10]. Azotobacter sp. fosfor çözen bakteri ve kimyasal gübre (N:P:K, 100:50:00 kg/ha) uygulamalarının sarımsak cv. G-41 türünün bitki yüksekliği, yaprak sayısı, soğan çapı, taze soğan ağırlığını önemli derecede arttırdığı tespit edilmiştir [11]. Benzer sonuçlar soğan bitkisi ile yapılan çalışmada da ortaya konulmuştur [12,13].

Çalışmada ile daha önce yürütülen pek çok çalışmadan izole edilen, azot fiksasyonu ve fosfat çözebilme özellikleri bakımından karakterize edilen, hormon üretimi, amino ve organik asit üretimleri bakımından da test edilen çok sayıdaki izolat arasından seçilerek oluşturulan 3 farklı biyoformülasyonun sarımsakta (Allium sativum L.) bitki boyu, klorofil düzeyi ve bazı enzim (katalaz, peroksidaz, polifenol oksidaz ve superoksit dismutaz) aktiviteleri üzerine etkileri araştırılmıştır.

\section{Materyal ve Metot}

\subsection{Materyal}

Araştırmada kullanılan bakteriler Tablo 1'de verilmiştir. Tablo 1 incelendiğinde; yabani ve kültür bitkilerinin toprak altı veya toprak üstü aksamlarından izole edilerek tanılanan, biyolojik mücadele ve bitki büyüme ajanı özelliğine sahip toplam 1248 bakteri izolatı içerisinden seçilen Agrobacterium sp., Bacillus sp., Pantoea sp. ve Pseudomonas sp.’e ait toplam 19 adet antagonist bakteri izolatı kullanılmıştır [14, 15]. Bu bakteri izolatlar, moleküler sistemlerden yağ asidi methil esterlerini esas alan MIS (Microbial Identification System) sistemi kullanılarak tanılanmış olup; Atatürk Üniversitesi, Ziraat Fakültesi, Bitki Koruma Bölümü’nde Mikroorganizma Kültür Koleksiyonunda muhafaza edilmektedirler.

Tablo 1. Çalışmada kullanılan bakteri türleri

\begin{tabular}{llllll}
\hline Sıra no & İzolat no & Bakteri türü & Sira no & İzolat no & Bakteri türü \\
\hline $\mathbf{1}$ & A-1 & Agrobacterium rubi & $\mathbf{1 1}$ & TV-12H & Bacillus subtilis \\
$\mathbf{2}$ & A-16 & Agrobacterium rubi & $\mathbf{1 2}$ & TV-20E & Bacillus megaterium \\
$\mathbf{3}$ & BA-8 & Pseudomonas putida & $\mathbf{1 3}$ & TV-60D & Bacillus megaterium \\
$\mathbf{4}$ & FDG-37 & Pseudomonas flourescens & $\mathbf{1 4}$ & TV-67C & Bacillus pumilus \\
$\mathbf{5}$ & KBA-10 & Bacillus megaterium & $\mathbf{1 5}$ & TV-6D & Bacillus megaterium \\
$\mathbf{6}$ & M-3 & Bacillus megaterium & $\mathbf{1 6}$ & TV 6F & Bacillus subtilis \\
$\mathbf{7}$ & RK-205 & Pantoea agglomerans & $\mathbf{1 7}$ & TV-87A & Bacillus megaterium \\
$\mathbf{8}$ & RK-79 & Pantoea agglomerans & $\mathbf{1 8}$ & TV-91C & Bacillus megaterium \\
$\mathbf{9}$ & RK-92 & Pantoea agglomerans & $\mathbf{1 9}$ & TV-3D & Bacillus megaterium \\
\hline
\end{tabular}

Çalışmada 3 farklı biyoformülasyon (F1, F2 ve F3) kullanılmış olup; kullanılan biyoformülasyonları oluşturan bakteri izolatları Tablo 2'de verilmiştir. Biyoformülasyonlar oluşturulurken bakterilerin hormon üretimleri, amino asit ve organik asit üretim değerleri dikkate alınmıştır [16,17]. Ultra derin dondurucuda (- 86 
$\left.{ }^{\circ} \mathrm{C}\right)$ muhafaza edilen bakteriler derin dondurucudan çıkarılarak buzunun çözülmesi için beklenilmiş, her bir bakteri Nutrient Agar (NA, Oxoid) besiyerine 3 faz çizilerek 24 saatlik taze kültürleri elde edilmiştir. Bu taze kültürlerden bir öze dolusu bakteri alınarak içerisinde $50 \mathrm{ml}$ Nutrient Broth (NB, Oxoid) besi yeri bulunan sıvı kültürlere ekim yapılmıştır. Kültürler yatay çalkalayııılı $26 \pm 2{ }^{\circ} \mathrm{C}$ inkübatörde 48 saat inkübasyona bırakılmıştır.

Tablo 2. Kullanılan biyoformülasyonları olușturan bakteri izolatları

\begin{tabular}{|c|c|c|c|c|c|c|c|c|c|c|c|c|}
\hline \multirow[b]{2}{*}{$\mathbf{F 1}$} & \multicolumn{4}{|c|}{ Hormon grubu bakteriler } & \multicolumn{8}{|c|}{ Amino asit ve organik asit grubu bakteriler } \\
\hline & TV-6D & TV-60D & TV-20E & A-1 & RK-92 & RK-205 & TV-67C & TV-87A & M-3 & BA-8 & KBA-10 & FDG-37 \\
\hline F2 & $\mathrm{TV}-12 \mathrm{H}$ & RK-79 & TV-91C & TV-11D & RK-92 & RK-205 & TV-67C & TV-87A & M-3 & BA-8 & KBA-10 & FDG-37 \\
\hline F3 & TV-6F & A-16 & TV-3D & TV-6D & RK-92 & RK-205 & TV-67C & TV-87A & M-3 & BA-8 & KBA-10 & FDG-37 \\
\hline
\end{tabular}

\section{2. $\quad$ Metot}

Her bir formülasyonda $50 \mathrm{ml}$ alınarak steril bir erlen içinde $450 \mathrm{ml}$ steril su ile karıştırılarak son formülasyonlar hazırlanmıştır. Bu bakteri formülasyonu içerisine daldırılan sarımsak dişleri 5 dakika bekletilerek içerisinde toprak bulunan plastik saksılara (saksı çap1 $15 \mathrm{~cm}$ ) $5 \mathrm{~cm}$ derinliğe dikilmiş̧ir. Her bir uygulama için 3 saksı ve her saksıda 3 sarımsak olacak şekilde çalışma 3 tekerürlü olarak kurulmuştur. Çalışma tesadüf parselleri deneme desenine göre sera ortamında yürütülmüş̧ür. Daldırma sonunda kalan bakteri formülasyonu 1/3 oranında su ile seyreltilerek dikimden sonra saksı başına 200 ml'lik olacak şekilde sulama suyu olarak kullanılmışır. Kalan formülasyonlar buzdolabında $\left(+5{ }^{\circ} \mathrm{C}\right)$ muhafaza edilmiş ve 10 gün ara ile 2 kez daha tekrar edilmiştir. Yedinci ve onbrinci günde boy ölçümleri; Onbirinci günde klorofil ölçümleri; Ellinci günde ise hasat edilerek enzim aktivitelerine bakılmıştır.

\subsection{Bitki analizleri}

\subsubsection{Yaprakta klorofil miktarı (SPAD değeri)}

Bitki örneklerinin klorofil içeriği SPAD-502 klorofil metre (Konica Minolta Sensing, Inc., Osaka, Japan) ile belirlenmiştir.

\subsubsection{Bitkilerde enzim aktivitelerinin belirlenmesi}

\subsubsection{Peroksidaz aktivitesinin belirlenmesi}

Peroksidaz (POD) aktivite tayini, guaikol ve $\mathrm{H}_{2} \mathrm{O}_{2}$ 'nin substrat olduğu reaksiyonun ürünü olan renkli bileşiğin meydana getirdiği absorbans artısının $470 \mathrm{~nm}$ 'de izlenmesi esasına dayanmaktadır [18]. Aktivite ölçümü için spektrofotometre (Shimadzu UV-VIS-1800 Spektrofotometre) küvetine; $100 \mathrm{~mL} 0.1 \mathrm{M}, \mathrm{NaH}_{2} \mathrm{PO}_{4}$ (pH: 5.5) ve $5 \mathrm{mM}$ guaikol içeren substrat çözeltisinden $3 \mathrm{~mL}$ konulduktan sonra, üzerine $10 \mu \mathrm{L}$ enzim ekstraktı ilave edilmiştir. 470 nm'de 5 dakika boyunca absorbans artısı 1 dakika aralıklarla kaydedilmiş ve absorbansın doğrusal olarak arttığı kısımdaki absorbans artısı 1 dakikaya oranlanmıştır. $25{ }^{\circ} \mathrm{C}$ 'de 1 dakikada, absorbansı 0.01 artıran enzim miktarı 1 enzim ünitesi olarak kabul edilmiş ve sonuçlar g yaprak basına düsen enzim ünitesi (EU/g yaprak) olarak sunulmuştur.

\subsubsection{Süperoksid dismutaz aktivitesinin belirlenmesi}


Süperoksid dismutaz (SOD) aktivitesi, nitro blue tetrazoliumun (NBT) süperoksit radikalleri ile mavi renkli formazona fotokimyasal indirgenmesi reaksiyonunun SOD enzimi tarafindan engellenmesinin

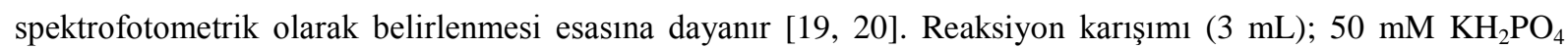
(pH: 7.8), 13 mM metiyonin, 75 mM NBT, 2 mM riboflavin ve 0.1 mM EDTA içermektedir. Aktivite ölçümü için $3 \mathrm{~mL}$ spektrofotometre küvetine yukarıdaki riboflavin içermeyen reaksiyon karışımdan $2.84 \mathrm{ml}$ alınmış ve üzerine $100 \mathrm{~mL}$ enzim ekstraktı pipetlemiştir. Reaksiyon, tüp üzerine $100 \mathrm{mM}$ 'llk riboflavin çözeltisinden 60 $\mathrm{mL}$ pipetle eklenip karıştırıldıktan hemen sonra, beyaz bir 1şık kaynağı önüne yerleştirmek suretiyle başlatılmıştır. Tüp, ışık kaynağının karsısında $15 \mathrm{dk}$. tutulmuş ve reaksiyon ışık kaynağının kapatılmasıyla durdurulmuştur. 15 dk. içerisinde NBT'nin renk açılma yoğunluğu 560 nm’de köre karşı okunmuştur. Kör; aynı işlemin enzimsiz örneğinden oluşmaktadır. SOD aktivitesinin 1 ünitesi, 560 nm'de gözlenen NBT indirgenmesinin \% 50 inhibisyonuna neden olan enzim miktarı, 1 enzim ünitesi olarak kabul edilmiş ve değerler EU/g yaprak olarak sunulmuştur.

\subsubsection{Katalaz aktivitesinin belirlenmesi}

Katalazın (CAT) aktivite tayini Havir ve Mchale ile Luck'un kullandığı yönteme göre yapılmıştır [21, 22], dayandırarak uyguladığı yöntemdir. Bu metotla aktivite ölçümü, CAT aktivite ölçüm ortamındaki $\mathrm{H}_{2} \mathrm{O}_{2}$ 'nin $\mathrm{O}_{2}$ ve $\mathrm{H}_{2} \mathrm{O}$ 'ya dönüşümünü sağlarken meydana gelen absorbans azalmasının $240 \mathrm{~nm}$ 'de izlenmesi esasına dayanır [21]. Reaksiyonda azalan $\mathrm{H}_{2} \mathrm{O}_{2}$ miktarını belirlemede kullanılan olan $\mathrm{H}_{2} \mathrm{O}_{2}$ standart grafiği önceden hazırlanmıştır. Bunun için, $5 \mathrm{mM} \mathrm{H} \mathrm{O}_{2}$ çözeltisinden $3 \mathrm{~mL}$ 'lik spektrofotometre tüpüne sırasıyla; $0.15,0.3,0.45$, 0.6, $0.75,0.9,1.05,1.2,1.35$ ve $1.5 \mathrm{~mL}$ konulmuştur. Tüpün hacmi saf su ile $1.5 \mathrm{~mL}$ 'ye tamamlanmış ve her tüpe $1.47 \mathrm{~mL}, 103.5 \mathrm{mM} \mathrm{KH} \mathrm{KO}_{4}$ ve $30 \mu \mathrm{L}$ su ilave edilmiştir. Küvet spektrofotometreye yerleştirildikten sonra 240 nm'de absorbans köre karsı okunmuştur. Absorbans değerlerine karşılık gelen $\mu \mathrm{M} \mathrm{H}_{2} \mathrm{O}_{2}$ değerleri kullanarak standart grafik elde edilmiştir. Aktivite ölçümü için $3 \mathrm{~mL}$ 'lik spektrofotometre küvetine, $103 \mathrm{mM} \mathrm{KH_{2 } \mathrm { PO } _ { 4 }}$

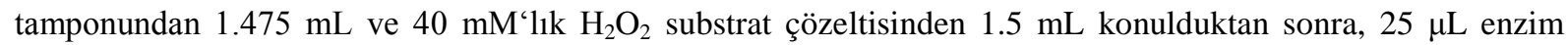
ekstraktı ilave edilmiştir. Küvet spektrofotometreye yerleştirildikten sonra 240 nm'de 3 dakika boyunca 1 dakika aralıklarla köre karşı absorbansı okunmuştur. Ölçümlerde absorbansın doğrusal olarak azaldığı aralıktan dakika başına absorbans azalması hesaplanmıştır. Bu ortalama absorbans değerleri, standart grafik yardımıyla $\mu$ mol cinsinden $\mathrm{H}_{2} \mathrm{O}_{2}$ miktarına dönüştürülmüştür. $25^{\circ} \mathrm{C}$ 'de, 1 dakika içinde, absorbansı $1 \mu$ mol azaltan enzim miktarı 1 enzim ünitesi olarak kabul edilmiş ve sonuçlar g yaprak basına düşen enzim ünitesi (EU/g yaprak) olarak sunulmuştur.

\subsubsection{Polifenoloksidaz aktivitesinin belirlenmesi}

Polifenol oksidaz aktivitesi Flurkey’e göre belirlenmiştir [23]. Aktivite ölçümü, bir o-fenol olan katekolün oksijen mevcudiyetinde oldukça dayanıklı bir form olan kahverengi-sarı renkli bir kinona dönüşürken meydana gelen renk değişiminin sebep olduğu absorbans artışının $420 \mathrm{~nm}$ 'de izlenmesi esasına dayanır. Aktivite ölçümü için 30 ml'lik spektrofotometre küvetine; $100 \mathrm{ml} 0.2 \mathrm{M}$ sodium fosfat tampon ve $25 \mathrm{mM}$ katekol içeren substrat çözelt isinden $3 \mathrm{ml}$ konulduktan sonra inkübasyon ortamına $100 \mu \mathrm{L}$ hazırlanan simplastik homojenat veya apoplastik çözelti ilave edilmiştir. $420 \mathrm{~nm}$ 'de $5 \mathrm{dk}$ boyunca absorbans artış1 1 dakika aralıklarla kaydedilmiştir. Örneklerin her birinde üçer tekerrür yapılarak absorbans ortalamaları belirlenmiştir. Ölçümlerde absorbansın lineer olarak arttığı kısımdaki absorbans artışı 1 dakikaya oranlanmıştır. Daha sonra gram başına 
absorbans değeri belirlenmiştir. $25^{\circ} \mathrm{C}$ 'de 1 dakikada absorbansı 0.001 arttıran enzim miktarı 1 enzim ünitesi olarak kabul edilmiştir. Sonuçlar g yaprak başına düşen enzim ünitesi (EU/g yaprak) olarak verilmiştir.

\subsubsection{Antioksidan enzim testleri}

Bitkiler kurutultuktan sonra metanol çözelti ekstraktı hazırlanmıştır [24, 25]. Kuru biyomassın konsantrasyonu $10 \mathrm{~g} / \mathrm{L}$ olmak üzere hazırlanmıştır. Ekstraktlarımızı elde etmek için rotary evaporator cihazı (Heidolph, Almanya) kullanılmıştır. Elde edilen ekstraklar $3 \mathrm{ml}$ çözeltide tekrardan süspanse edilip antioksidant analizleri yapılması için buzdolabında muhafaza edilmiştir [26]. Trolox Equivalent Antioxidant capacity (TAC) testleri ticari kit kullanılarak (Total Antioxidant Status, Rel Assay Diagnostics, Turkey) yürütülmüştür [27].

\subsection{Toprak analizleri}

Toprakların tekstürleri Bouyoucus Hidrometre yöntemiyle [28]; pH's1 pH metre ile [29]; kireç içerikleri Scheibler Kalsimetresi ile volümetrik olarak [30]; organik madde içerikleri Smith-Weldon yöntemiyle [31] katyon değişim kapasiteleri ve değişebilir katyonlar ICP-OES spektofotometresinde [32] belirlenmiştir.

\subsection{Formülasyonların topraktaki mikrobiyal fauna üzerine etkisinin belirlenmesi}

$\mathrm{Bu}$ amaçla; deneme başında saksılara aktarılan edilen topraktan alınan örneğe ilave olarak, hasat sonunda da her bir saksının toprağı iyice karıştırılarak o saksıyı temsilen 100 gr toprak örneği alınmıştır. Her bir uygulamaya ait 9 saksıdan alınan örnekler yeniden iyice karıştırılarak o uygulamayı temsil edecek şekilde analiz edilecek toprak örneği oluşturulmuştur. Toprak örnekleri elekten geçirilerek taş ve kaba örnekler ayıklandıktan sonra iyice karıştırılarak o uygulamayı temsilen 1 gr toprak örneği salina tampon çözeltisi (\%0.85'lik $\mathrm{NaCl})$ içerisinde süspanse edilmiştir. Örnekler 500 rpm'de santrifüj edilerek büyük partiküller çöktürülmüş ve üstte kalan süspansiyon Biolog Sisteminde (Biolog, U.S.A. SN E11175) Eco Plate, GN2, GP2, YT ve FF mikro plate üzerindeki her bir çukurcuğa $130 \mu$ l eklenerek, plateler 12 saat süreyle $26{ }^{\circ} \mathrm{C}$ 'de inkübasyona bırakılmıştır. İnkübasyon sonrası mikroplateler üzerinde gelişen renklenmeler gözlenerek, test edilen toprak örneklerinin metabolik reaksiyon profilleri biolog kinetik (Program: Biolog MicroLog3 4.20, $\lambda_{1}=405 \mathrm{~nm} \quad \lambda_{2}=750 \mathrm{~nm}$ ) okuyucu ile okunmuştur Kontrol ile bakteri uygulaması yapılan alanlara ait toprak örneklerinin uygulandığı mikroplate üzerindeki pozitif reaksiyonlar kayıt edilerek \% karbon kaynağı kullanım oranları belirlenmiştir. Karbon kullanım oranlarının yüksek olması mikrobiyal faunanın zenginliğinin bir göstergesi olarak değerlendirilmiştir.

\section{7. İstatistiki analizler}

Sonuçlar; SPSS (Statistical Package for Social Sciences, Version 9.0) istatistik programında varyansı analizine göre değerlendirilmiştir. Uygulamamalar arasındaki farklılığın önem derecesini belirlemek için varyans analizi ve Duncan testi yapılmıştır [33].

\section{Bulgular}


Deneme toprağının bazı kimyasal analiz sonuçları Tablo 3'de verilmiştir. Görüldüğü gibi toprak pH’sı hafif alkalin, organik madde içeriği az sınıfına girmektedir. Kireç içeriği yönünden az, K ve Ca içeriği bakımından fazla, $\mathrm{Mg}$ yeter ve fazla, $\mathrm{P}$ bakımından yetersiz, elverişli Fe içeriği yönünden orta, $\mathrm{Zn}$ ve $\mathrm{Cu}$ içeriği yönünden yeterli sinıfina girmektedir [34-35].

Tablo 3. Denemede kullanılan toprak örneklerine ait bazı kimyasal analiz sonuçları

\begin{tabular}{ll}
\hline Toprak özellikleri & Değer \\
\hline $\mathrm{pH}(1: 2,5)$ & 7.52 \\
$\mathrm{CaCO}, \%$ & 0.78 \\
Organik madde, \% & 1.43 \\
$\mathrm{NH} 4-\mathrm{N}, \mathrm{mg} / \mathrm{kg}$ & 8.63 \\
$\mathrm{NO} 3-\mathrm{N}, \mathrm{mg} / \mathrm{kg}$ & 9.78 \\
$\mathrm{KDK}(\mathrm{me} / 100$ gr) & 24.16 \\
\hline
\end{tabular}

Biyoformülasyonların bitki boyu ve klorofil değerleri üzerine etkisini gösteren sonuçlar Tablo 3.2'de verilmiştir. Araştırma sonucunda; tüm bakteri formülasyonu uygulamaları yedi ve onbirinci günde yapılan değerlendirmelerde bitki boyunda ve onbirinci günde klorofil düzeyinde bir miktar artış veya azalışlara sebep olmuş, bitki boyundaki farklılıklar kontrole göre istatistiki olarak önemli bulunurken klorofil oranındaki değişiklikler önemli bulunmamıştır (Tablo 3). Bitki boyu açısından F2 ve F3 formülasyonlarının F1 fomülasyonuna oranla daha etkin oldukları tespit edilmiştir.

Tablo 3.4. Biyoformülasyonların bitki boyu ve klorofil değerleri üzerine etkisi

\begin{tabular}{cccr}
\hline Uygulamalar & 7. gün boy $(\mathbf{c m})$ & 11. gün boy (cm) & 11. gün Klorofil okuma \\
\hline F1 & $9.25 \pm 7.37^{*}$ & $26.41 \pm 4.14$ & $35.02 \pm 2.16^{* *}$ \\
F2 & $14.92 \pm 4.57$ & $29.07 \pm 3.24^{* *}$ & $34.95 \pm 3.65^{* *}$ \\
F3 & $16.70 \pm 6.59$ & $29.10 \pm 5.61^{* *}$ & $32.68 \pm 2.42^{*}$ \\
Kontrol & $16.16 \pm 5.44$ & $27.00 \pm 4.30$ & $35.78 \pm 2.93$ \\
F & 1.9 & 0.63 & 3.95 \\
\hline
\end{tabular}

Ortalama \pm standart sapma, *: $\mathrm{p}=0.1$ and $* *: \mathrm{p}=0.5$

Biyoformülasyonların bitkideki antioksidant enzim aktiviteleri (EU/mL) üzerine etkisini gösteren sonuçlar Tablo 3.3'de verilmiştir. Bu sonuçlara göre; F1 ve F2 bakteri formülasyonu uygulamaları savunma mekanizmasında görev olan tüm enzim düzeylerinde kontrole göre artışlara sebep olmuştur. F3 bakteri formülasyonu ise peroksidaz ve polifenol oksidaz enzim düzeylerinde azalışa katalaz ve süperoksit dismutaz enzimleri düzeyinde ise kontrole göre artışlara sebep olmuştur.

Tablo 5. Biyoformülasyonların bitkideki antioskidant enzim aktiviteleri (EU/mL) üzerine etkisi

\begin{tabular}{ccccc}
\hline Uygulamalar & Katalaz & Peroksidaz & Polifenol oksidaz & Süperoksit dismutaz \\
\hline F1 & $3.24 \pm 0.11$ & $78.5 \pm 1.70$ & $0.70 \pm 1.40$ & $172.20 \pm 1.60$ \\
F2 & $3.46 \pm 2.10$ & $159.2 \pm 0.50$ & $1.05 \pm 0.70$ & $252.40 \pm 2.30$ \\
F3 & $1.07 \pm 1.11$ & $65.1 \pm 2.40$ & $0.26 \pm 2.30$ & $140.20 \pm 0.45$ \\
Kontrol & $0.17 \pm 4.01$ & $69.2 \pm 1.80$ & $0.48 \pm 1.05$ & $20.26 \pm 2.20$ \\
\hline
\end{tabular}


Uygulamaların bitkinin farklı organlarındaki antioksidan enzim düzeylerine etkisini gösteren sonuçlar Tablo 6'da verilmiştir. Yine bakteri uygulamalarının yaprak, kök, soğan ve gövdede toplam antioksidan enzim düzeylerinde de artış veya azalışlara sebep olduğu görülmüş ancak bu değişiklikler istatistiki olarak önemli bulunmamıştır.

Table 6. Biyoformülasyonların bitkideki antioksidan enzim aktiviteleri üzerine etkisi ( $\mathrm{m} \mathrm{mol} / \mathrm{L})$

\begin{tabular}{|c|c|c|c|c|c|c|c|c|}
\hline \multirow[t]{2}{*}{ Uygulamalar } & \multicolumn{4}{|c|}{ Antioksidant (metanol) } & \multicolumn{4}{|c|}{ Antioksidant (damıtma metanol) } \\
\hline & Yaprak & Kök & Soğan & Gövde & Yaprak & Kök & Soğan & Gövde \\
\hline F1 & 1.41 & 1.74 & 0.80 & 1.11 & 0.23 & 0.39 & 0.19 & 0.42 \\
\hline F2 & 1.37 & 0.78 & 0.69 & 1.51 & 0.36 & 0.36 & 0.16 & 0.19 \\
\hline F3 & 1.34 & 1.70 & 1.14 & 1.44 & 0.42 & 1.18 & 0.17 & 0.32 \\
\hline Kontrol & 2.13 & 1.05 & 0.89 & 1.28 & 0.32 & 0.32 & 0.26 & 0.30 \\
\hline
\end{tabular}

Biyoformülasyonların topraktaki mikrobiyal faunaya etkisini gösteren sonuçlar Tablo 3.5'de verilmiştir. BIOLOG sisteminde yapılan bu değerlendirmelerde uygulamaların topraktaki Gram pozitif ve Gram negatif bakteri, maya ve fungus faunası açısından önemli bir değişime sebep olmadığı tespit edilmiştir. Karbon kaynakları kullanım yüzdeleri açısından topraklarda büyük bir benzerliğin olduğu tespit edilmiştir.

Table 7. Biyoformülasyonların topraktaki mikrobiyal faunaya etkisi

\begin{tabular}{|c|c|c|c|c|}
\hline \multirow[t]{2}{*}{ Uygulamalar } & \multicolumn{4}{|c|}{ Kullanılan karbon kaynaklarının oranı (\%) } \\
\hline & FF plate & GP2 plate & GN2 plate & YT plate \\
\hline F1 & 61 & 81 & 81 & 20 \\
\hline $\mathrm{F} 2$ & 76 & 78 & 79 & 32 \\
\hline F3 & 73 & 75 & 78 & 28 \\
\hline Kontrol & 75 & 73 & 76 & 24 \\
\hline
\end{tabular}

\section{Tartışma ve Sonuç}

Çalışma; sarımsak yetiştiriciliğinde kimyasal gübre kullanımını azaltacak mikrobiyal gübre formülasyonu geliştirilmesi bakımından bir ön çalışma niteliğindedir. Saksıda yürütülen çalışmada bakteri formülasyonlarının temel bazı bitki gelişim parametrelerine etkileri incelenmiştir. Özellikle şekil 1'e bakıldığında bakterilerin sarımsak bitkisinin kök gelişimine çok ciddi bir etkisi olmuştur. Her üç formülasyon kök gelişimine etkisi kontrole oranla daha yüksek bulunmuştur. Bitki boyunda yapılan ölçümlerde ise kontrol ile bu kadar farklılık bulunamamıştır. Tarla koşullarında yürütülmesi planlanan çalışmada kök gelişimlerinin sarımsak diş sayısı ve ağırlığında çok olumlu katkılar sağlayacağı düşünülmektedir. 


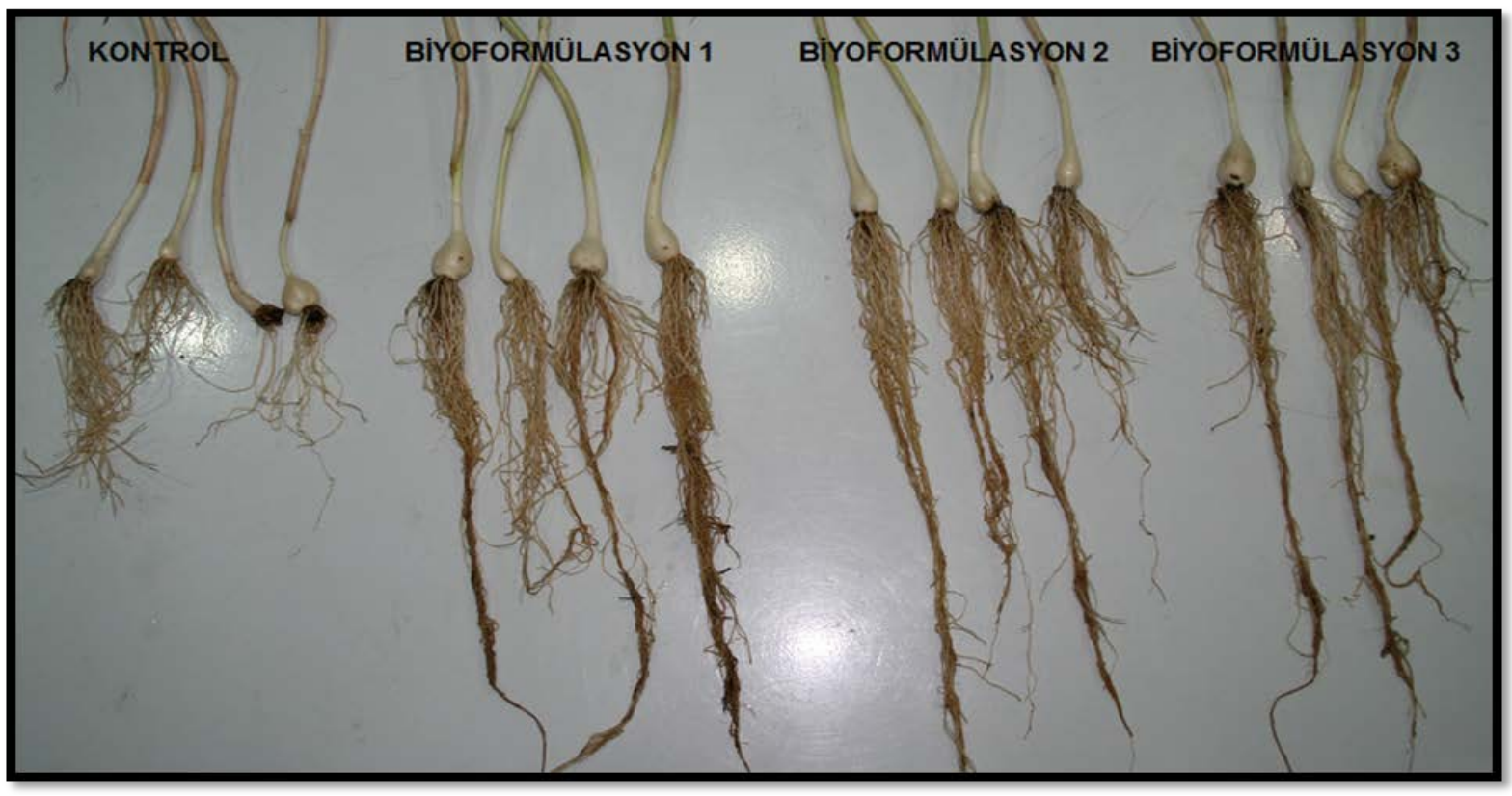

Şekil 1. Bakteri biyoformülasyon uygulamalarının saçak kök gelişimine etkisi

Bakteri uygulamalarının farklı bitkilerde bitki gelişimi üzerine etkilerinin belirlendiği çok sayıda çalışma bulunmaktadır. Yapılan bir çalışmada, Mesorhizobium sp. ve Pseudomonas aeruginosa bakteri straini uygulamalarının nohut bitkisinin besin elementi alımı ve bitki gelişimine önemli katkılar sağladığını belirlemişlerdir [36]. Brokolinin bitki ağırlığı, bitki çapı ve klorofil içeriği üzerine uygulamış oldukları Bacillus cereus (BC), Rhizobium rubi (RR) ve Brevibacillus reuszeri (BR) bakteri biyoformülasyon grubları kontrol ile karşılaştırıldığında önemli düzeyde katkı sağladığını bildirmişlerdir [37]. Benzer diğer çalışmalarda domates [38, 39], arpa ve şeker pancarı [40, 41], buğday ve ıspanak [42], kanola [43], mısır [44], mısır ve buğday [45] bitkilerinin gelişim parametreleri üzerine farklı bakteri uygulamalarının etkili olduğu tespit edilmiştir.

Ancak; tarafımızdan yapılan araştırmada PGPR bakteri uygulamalarının sarımsak gelişimi üzerine etkisini araştıran çalışmaya fazla rastlanmamıştır. Yapılan bir çalışmada; sarımsak bitkisinin gelişimi üzerine etkisinin test edilmesi için izole edilen 7 farklı (S1, S2, S3, S4, S5, S6 ve S7) bakteri uygulamasında S3 bakteri uygulamasının kök uzunluğu, bitki boyu, diş çapı, taze ve kuru ağırlık üzerine önemli katkıları olduğunu tespit etmişlerdir [46]. Bakteri uygulamalarının sarımsakta enzim ve antioksidan düzeylerine etkisini araştıran çalışmaya ise hiç rastlanmamıştır. Bu çalışmada farklı bakteri biyoformülasyon uygulamalarının sarımsak bitkisinin enzim aktivitesinde meydana getirdiği değişimler incelendiğinde özellikle F2 formülasyonunun test edilen 4 stres enzimi düzeyinde de artışa sebep olduğu görülmektedir.

Daha önce farklı bitki gruplarında yürütülen çalışmalarda PGPR bakterilerinin bitkilerde stres enzimleri ve antioksidan enzim düzeylerinde artışlara sebep olduğu görülmüştür [47, 48, 49]. Rizobakteri strainlerinin çoğunun tuzluluğa, kuraklığa, su baskınına, bitki hastalıklarına ve ağır metal toksisitesine karşı bitkinin antioksidant içeriğini artırarak bitkinin toleransını geliştirdiği belirlenmiştir [50, 51, 52]. ACC deaminaze içeren bitki gelişmesini teşvik edici bakteri uygulamaları etilen düzeyinin azalmasını sağlayarak farklı çevresel streslere karşı bitkilerin daha dayanıklı olmasını ve bitkide oluşan etilen hormon üretimini dengeleyerek bitki büyüme ve gelişimini teşvik etmektedir [1, 53]. Ayrıca ACC-deaminaz aktivitesinin bitki gelişimini engelleyen aşırı su [54] 
ve kuraklık [55] stresine karşıda bitkilerde koruma sağladığı belirlenmiştir. PGPR izolatları ve buğday bitkisi ile kuraklığın yaşandığı bir bölgede yapılan araştırmada PGPR uygulamasının kuraklık üzerine etkin olduğu tespit edilmiştir [56]. Kuraklık stresi altındaki mısır bitkisine PGPR bakteri uygulamasıyla aminoasit, çözünebilir şeker ve prolin birikimin arttırdığı belirlenmiştir [57]. Bitki gelişimi engelleyen önemli faktörlerden biri olan bitki hastalıklarının da azaltılmasında da PGPR bakterilerinin etkin olduğu bildirilmiştir [58, 59]. Yapılan bir çalışmada asmada ur hastalı̆̆ı üzerine izole edilen farklı PGPR bakteri uygulamasının hastalığı önemli düzeyde azalttığını [60] başka bir çalışmada ise PGPR izolatlarının biberde Xanthomonas axonopodis pv. vesicatoria’ya karşı kullanıldığında hastalık şiddetini \% 65 oranında azalttığı belirtilmiş̧ir [61]. PGPR uygulamalarının önemli stres faktörlerinden biri olan soğuk stres üzerine etkileri de yapılan birçok çalışmada açık bir şekilde gösterilmiştir. Yapılan bir çalışmada soğuk stres altındaki buğday ve arpa bitkilerinin antioksidant enzim (SOD, POD, CAT) aktiviteleri üzerine iyileştirici etkileri olduğu belirlenmiştir [62]. Yine soğuk stresinin olumsuz etkileri üzerine PGPR uygulamaları ile buğday, salatalık [63, 64] ve pirinç [65] bitkilerinin gelişiminde iyileştirici etkileri tespit edilmiştir. Farklı tuz stresi altındaki mısır bitkisine PGPR uygulamaları ile bitki gelişimi, potasyum ve fosfor alımının arttığı belirlenmiştir [66]. Tuz stresi altında bulunan kanola bitkisine uygulanan çeşitli PGPR ların bitki gelişim ve biyokütlesinin artışına önemli katkılar sağladığı belirtilmiştir [67]. $\mathrm{Bu}$ çalı̧̧mada elde edilen sonuçlarda bakteri uygulamalarının bitki gelişim parametreleri yanında stres koşullarına karşıda bitkilerde bir koruma sağlayacağı düşünülmektedir.

Sonuç olarak; test edilen 3 bakteri biyoformülasyonu içerisinde özellikle F2 formülasyonunun hem bitki gelişim parametreleri hem de bitkideki enzim düzeyleri bakımından yapılan değerlendirmede sarımsak tarımında mikrobiyal gübre olarak kullanılabileceği düşünülmektedir. Bu formülasyonun arazi koşullarında test edilmesi planlanmaktadır.

\section{Kaynaklar}

[1] Glick, B.R., Penrose, D.M., Li, J., "A model for the lowering of plant ethylen concentrations by plant growth-promoting bacteria” Journal of Theoretical Biology, 190: 63-68, 1998

[2] Karagöz, K. ve Kotan, R., "Bitki gelişimini teşvik eden bazı bakterilerin marulun gelişimi ve bakteriyel yaprak lekesi hastalığı üzerine etkileri” Türkiye Biyoloji Mücadele Dergisi, 1(2): 165-179, 2010

[3] Bhattacharyya, P., Jha, D., "Plant growth-promoting rhizobacteria (PGPR): emergence in agriculture" World Journal of Microbiology and Biotechnology, 1-24, 2012

[4] Alizadeh, H., Behboudi, Keivan., Ahmadzadeh, M., Javan-Nikkhah, Mohammad., Zamioudis, C., Pieterse, C.M.J., Bakker, P.A.H.M., “ Induced systemic resistance in cucumber and Arabidopsis thaliana by the combination of Trichoderma harzianum Tr6 and Pseudomonas sp.” Biological Control, 65: 14-23, 2013

[5] Taban, S., Turan, M.A.,Sezer, S.M., Türkmen, N., "Kastamonu taşköprü yöresinde yetiştirilen sarımsak bitkisinin selenyum içerikleri ve bazı toprak özellikleri arasındaki ilişkiler” Süleyman Demirel Üniversitesi Ziraat Fakültesi Dergisi, 27 (1): 39-47, 2012

[6] Ipek, M., Ipek, A., Simon, P. W., "Molecular characterization of Kastamonu garlic: An economically important garlic clone in Turkey” Scientia Horticulturae, 115 (2): 203-208, 2008 
[7] Taban, S., Çıkılı, Y., Kebeci, F., Taban, N., Sezer, S. M., “ Taşköprü yöresinde sarımsak tarımı yapılan toprakların verimlilik durumu ve potansiyel beslenme problemlerinin ortaya konulması” Tarım Bilimleri Dergisi, 10 (3): 297-304, 2004

[8] Günay, A., “Sebzecilik” Cilt 2, Ankara, 1983

[9] Chattoo, M.A., Ahmed,N., Faheema, S., Narayan, S., Khan, S.H., Hussain, K., "Response of garlic (Allium sativum L.) to biofertilizer application” The Asian Journal of Horticulture, 2 (2): 249-252, 2007

[10] Abdel-Razzak, H.S., El-Sharkawy, G.A., "Effect of biofetilizer and humic acid applications on growth, yield, quality and storability of two garlic (Allium sativum L.) cultivars” Asian Journal of Crop Science, 5 (1): 48-64, 2013

[11] Gaiki, U:R., Jogdande, N.D., Dalal, S.R., Nandre, D.R.,Ghawade, S.M., "Effect of biofertilizersunder reduced doses of inorganic fertilizers on growth and yield of garlic" Journal Plant Archives, 6 (1): 367368, 2006

[12] El-Desuki, M., Mahmoud, A.R., Hafiz, M.H., "Response of onion plants to minerals and biofertlizers application” Resource Journal Agriculture Biological Science, 2: 292-298, 2006

[13] Yaso,I.A., Abdel-Razzak, H.S., Wahab-Allah, M.A., "Influence of biofertlizer and mineral nitrogen on onion growth yield and quality under calcareous soil conditions” Jounal Agriculture Environmental Science, 6(1): 245-264, 2007

[14] Kotan, R., Sahin, F., Ala, A., "Identification and pathogenicity of bacteria isolated from pome fruits trees in eastern Anatolia region of Turkey” Journal of Plant Diseases and Protection, 113(1): 8-13, 2005

[15] Erman, M., Kotan, R., Çakmakçı, R., Çı̆̆g, F., Karagöz, F., Sezen, M., “Van Gölü Havzası'ndan izole edilen azot fikseri ve fosfat çözücü bakterilerin buğday ve şeker pancarında büyüme ve verim özellikleri üzerine etkileri” Türkiye IV. Organik Tarım Sempozyumu 28 Haziran-1 Temmuz, s 325-329, Erzurum, 2010

[16] Ekinci, M., Turan, M., Yildirim, E., Güneş, A., Kotan, R. and Dursun, A., "Effect of plant growth promotıng rhizobacteria on growth, nutrient, organic acid, amıno acid and hormone content of caulıflower (Brassica oleracea L. var. botrytis) transplants” Acta Scientiarum Polonorum, 13 (6): 7185, 2014

[17] Turan, M., Ekinci, M., Yildirim, E., Güneş, A., K. Karagöz, Kotan, R., Dursun, A., “Plant growthpromoting rhizobacteria improved growth, nutrient, and hormone content of cabbage (Brassica oleracea) seedlings” Turkish Journal of Agriculture and Forestry, 38: 327-333, 2014

[18] Angelini, R., Federico, R., "Histochemical evidence of poliamin oxidation and generation of hydrogen peroxide in the cell wall” Journal of Plant Physiology, (135): 212- 217, 1989

[19] Agarval, S., Pandey, V., “Antioxidant enzyme responses to $\mathrm{NaCl}$ stress in Cassia angustifolia” Biologia Plantarum, 48 (4): 555-560, 2004

[20] Yordanova, R.Y., Christov, K.N., Popova, L.P., “Antioxidative enzymes in barley plants subjected to soil flooding” Environmental and Experimental Botany, (51): 93-101, 2004

[21] Havir, E.A., Mchale, N.A., "Biochemical and developmental characterization of multiple forms of catalase in tobacco leaves” Plant Physiology, (84): 1291-1294, 1987 
[22] Luck, H., “Catalase In: Methods of Enzymatic Assays. (Ed.): H.U. Bergmeyer”. New York Academic Press, 885-894, 1965

[23] Flurkey, HW., “Polyphenoloxidase in higher plants” Plant physiology, 81: 614-618, 1986

[24] Katırcıŏlu, H., Beyatli, Y., Aslim, B., Yüksekdag, Z., Atici, T., "Screening of antimicrobial agent production of some microalgae in freshwater” The Internet Journal of Microbiology, 2: 2, 2006

[25] Abedin Rania, M. A., Taha Hala, M. T., “Antibacteriyal and antifungal activity of cyanobacteria and green microalgae evaluation of medium components by Plachett-Burman design for antimicrobial activity of Spirulina platensis” Global Journal of Biotechnology \& Biochemistry, 3 (1): 22-31, 2008

[26] Deshmukh, D.V., Puranik, P.R., "Application of Plackett-Burman Design to evaluate Media Components Affecting Antibacterial Activity of Alkaliphilic Cyanobacteria Isolated from Lonar Lake" Turkish Journal of Biochemistry, 35 (2): 114-120, 2010

[27] Türkez, H., Geyikoglu, F., Aslan, A., Karagöz, Y., Türkez, Ö., Anar, M., "Antimutagenic effects of lichen Pseudovernia furfuracea (L.) Zoph. extracts against the mutagenicity of aflatoxin B1 in vitro" Toxicology and Industrial Health, 26: 625, 2010

[28] Gee, G.W., Hortage, K.H., "Particle- size analysis. Methods of soil analysis. Part 1. Physical and minerological methods second edition” Agronomy, 9 (2): 383-441, 1986

[29] Mclean, E.O., "Soil pH and lime requirement. Methods of soil analysis part2. Chemical and microbiological properties second edition” Agronomy, 9 (2): 199-224, 1982

[30] Nelson, R.E., "Carbonate and gypsum. Methods of soil analysis Part2. Chemical and microbiological properties second edition” Agronomy, 9 (2): 191-197, 1982

[31] Nelson, D.W., Sommers, L.E. "Organic matter. Methods of soil analysis Part2. Chemical and microbiological properties second edition” Agronomy, 9 (2): 574-579, 1982

[32] Rhoades, J.D., "Cation Exchange Capacity . Methods of soil analysis Part 2. Chemical and microbiological properties second edition” Agronomy, 9 (2): 149-157, 1982

[33] SPSS, “SPSS 13.0 for Windows Evaluation version” (SPSS Inc., Illinois, USA), 2004

[34] Anonim, “Toprak Su İstatistikleri Bülteni”. Program ve Planlama Dairesi Başkanlığı Yayını, Ankara, 1980

[35] TOVEP, “Türkiye toprakları verimlilik envanteri”. T.C. Tarım Orman ve Köy İşleri Bakanlığı. Köy Hizmetleri Genel Müdürlüğü ve dayanıklılık ıslahı. Uludağ Üniversitesi Ziraat Fakültesi Dergisi, 9: 193-204, 1991

[36] Vermaa, J.P., Yaday,V., Tiwari, K.N., Kumar, A., "Effect of indigenous Mesorhizobium spp. and plant growth promoting rhizobacteria on yields and nutrients uptake of chickpea (Cicer arietinum L.) under sustainable agriculture” Ecological Engineering, 51: 282- 286, 2013

[37] Yıldırım, E., Karlıdağ, H., turan, M., Dursun, A., Göktepe, F., "Growth, nutrient uptake, and yield promotion of broccoli by plant growth promoting rhizobacteria with manure” Hortscience, 46 (6): 932 936, 2011.

[38] Turan, M., Özgül, M., Kocaman, A., "Freezing tolerance affected by mineral application during coldacclimated conditions in some cool crop seedlings" Commuitcations in Soil Science and Plant Analysis, 38 (7-8): 1047-1060, 2007 
[39] Gül, A., Kidoğlu, F., Tuzel, Y., Tuzel, I.H., "Effects of nutrition and Bacillus amyloliquefaciens on tomato (Solarium lycopersicum L.) growing in perlite” Spanish Journal of Agriculture Research, 6: 422-429, 2008

[40] Çakmakç1, R., Kantar, F., Şahin, F., "Effect of $\mathrm{N}_{2}$-fixing bacterial inoculations on yield of sugar beet and barley” Journal of Plant Nutrition and Soil Science, 164 (5): 527-531, 2001

[41] Şahin, F., Çakmakçı, R., Kantar, F., "Sugar beet and barley yields in relation to inoculation with $\mathrm{N}_{2}$ fixing and phosphate solubilizing bacteria” Plant Soil, 265: 123-129, 2004

[42] Çakmakçı, R., Erat, M., Erdoğan, Ü., Dönmez, F., “The influence of plant growth-promoting rhizobacteria on growth and enzyme activities in wheat and spinach plants” Journal of Plant Nutrition and Soil Science, 170: 288-295, 2007

[43] De Freitas, J.R., M.R. Banerjee, Germida., J.J., "Phosphate-solubilizing rhizobacteria enhance the growth and yield but not phosphorus uptake of canola” Biology Fertility Soils, 24: 358- 364, 1997

[44] Pal, S.S., “ Interaction of an acid tolerant strain of phosphate solubilizing bacteria with a few acid tolerant crops” Plant Soil, 198: 169-177, 1998

[45] Gurdeep, K., Reddy, S.M., "Effects of Phosphate-Solubilizing Bacteria, Rock Phosphate and Chemical Fertilizers on Maize-Wheat Cropping Cycle and Economics” Pedosphere, 25 (3): 428-437, 2015

[46] Fanh, W, L., Hong-mei, HE., JI, Guang-hai., G., "Effects of plant-growth promoting rhizobacteria on growth of garlic” Soil and Fertilizer Sciences, 3: 70-72, 2010

[47] Canellas, L.P., Teixeira Junior, L.R.L., Dobbs, L.B., Silva, C.A., Medici, L.O., Zandonadi, D.B., Facanha, A.R. "Humic acids cross-interactions with root and organic acids” Annals of Applied Biology, 153: 157-166, 2008

[48] Eyheraguibel, B., J. Silvestre., P. Morard., "Effects of humic substances derived from organic waste enhancement on the growth and mineral nutrition of maize” Bioresource Technology, 99: 4206-4212. 2008

[49] Tunc-Ozdemir, M., Miller, G., Song, L., Kim, J., Sodek, A., Koussevitzky, S., “Thiamin confers enhanced tolerance to oxidative stress in Arabidopsis” Plant Physiology, 151: 421-32, 2009

[50] Glick, B.R., “Using soil bacteria to facilitate phytoremediation” Biotechnology Advances, 28: 367-74, 2010

[51] Ma, Y., Prasad, M.N.V., Rajkumar, M., Freitas, H., “ Plant growth promoting rhizobacteria and endophytes accelerate phytoremediation of metalliferous soils” Biotechnology Advances, 29: 248-58, 2011

[52] Sandhya, V., Ali, S.K.Z., Grover, M., Reddy, G., Venkateswarlu, B., “Alleviation of drought stress effects in sunflower seedlings by the exopolysaccharides producing Pseudomonas putida strain GAPP45” Biology Fertilizer Soils, 46: 17-26, 2009

[53] Çakmakçı, R., "Mikrobiyal gübre olarak kullanılabilecek mikroroganizmaların etki mekanizmaları ve özellikleri” Mikrobiyal Gübre Çalıştayı, 5-17, 2014

[54] Mayak, S., Tirosh, T., Glick, B.R., "Plant growth-promoting bacteria confer resistance in tomato plants to salt stress” Plant Physiology and Biochemistry, 42: 565-572, 2004

[55] Grichko, V. P., Glick B. R., “Amelioration of flooding stres by ACC deaminase-containing plant growth-promoting bacteria” Plant Physiology Biochemistry, 39: 11-17, 2001 
[56] Bangash, N., Khalid, A., Mahmood, T., Tariq Siddique, M., "Screening Rhizbacteria containing ACCDeaminase for growth promoting of wheat under water stress” Pakistan Journal Botany, 45: 91-96, 2013

[57] Qudsaia, B., Noshinil, Y., Asghari, B., Nadia, Z., Abida, A., Fayazul, H., "Effect of Azospirillum inoculation on maize (Zea mays L.) under drought stress” Pakistan Journal Botany, 45: 13-20, 2013

[58] Pieterse, C.M.J., Van Pelt, J.A., Van Wees, S.C.M., Jurriaan, J., Leon-Kloosterziel, K.M., Keurentjes, J.J.B., Verhagen, B.W.M., Knoester, M., Sluis, I. Van der., Baker, P.A.H.M., Van Loon, L.C., "Rhizobacteria-mediated induced systemic resistance: Triggering, signaling and expression" European Journal of Plant Pathology, 107: 51-61, 2001

[59] Silva, H.S.A., Romeiro, R.S., Carrer Filho, R., Pereira, J.L.A., Mizubuti, E.S.G., Mounteer, A., “ Induction of systemic resistance by Bacillus cereus against tomato foliar diseases under field conditions” Journal of Phytopathology, 152: 371-375, 2004

[60] Küsek, M., Çınar, Ö., "Bitki büyümesini teşvik eden kök bakterilerini kullanılarak asma uru hastalığ1 etmeni Agrobacterium vitis'in biyolojik mücadelesi” Türkiye Biyolojik Mücadele Dergisi, 3(1): 21-36, 2012

[61] Mirik, M., "Biberde bakteriyel leke etmeni Xanthomonas axonopodis pv. vesicatoria'nın tanılanması ve bitki büyüme düzenleyici rhizobacteriler ile biyolojik mücadele olanakları" Çukurova Üniversitesi, Fen Bilimleri Enstitüsü, Doktora tezi, 162 s, Adana, 2005

[62] Turan, M., Güllüce, M., Çakmakc1, R., Şahin, F., "Effect of plant growth-promoting rhizobacteria strain on freezing injury and antioxidant enzyme activity of wheat and barley" Journal of Plant Nutrition, 36: 731-748, 2013

[63] Vagujfavi, A., Kerepesi, I., Galiba, G., Tischner, T., Sutka, J., "Frost hardiness depending on carbohydrate changes during cold acclimation in wheat” Plant Science, 144: 85-92, 1999

[64] Kang, S.M., Khan, A.L., Wagas, M., You, Y.H., Kim, J.H., Kim, J.G., Hamayun, M., Lee, I.J., “ Plant growth-promoting rhizobacteria reduce adverse effects of salinity and osmotic stress by regulating phytohormones and antioxidants in Cucumis sativus” Journal of Plant Interactions, 9 (1): 673-682, 2014

[65] Chang, M., W. Chien, C. Chao, Lu, M., " Effects of cold stress on alterations of physiochemical and chemical properties of rice polysaccharides” Carbohydrate Polymers, 80: 374-377, 2010

[66] Rojas-Tapias, D., Moreno-Galván , A., Pardo-Díaz, S., Obando, M., Rivera, D., Bonilla R. "Effect of inoculation with plant growth-promoting bacteria (PGPB) on amelioration of saline stress in maize (Zea mays)" Applied Soil Ecology, 61: 264-272, 2012

[67] Noorieh, B., Arzanesh, M.H., Mahlegha, G., Maryam, S., "The effect of plant growth promoting rhizobacteria on growth parameters, antioxidant enzymes and microelements of canola under salt stress" Journal of Applied Environmental Biological Science, 3: 17-27, 2013 